\title{
Status of Sea Urchin Resources in the East Coast of Borneo
}

\author{
Siti Akmar Khadijah Ab Rahim and Raymie Nurhasan \\ Department of Aquatic Science, Faculty of Resource Science and Technology, Universiti Malaysia Sarawak, \\ 94300 Kota Samarahan, Sarawak, Malaysia
}

Correspondence should be addressed to Siti Akmar Khadijah Ab Rahim; arakmar@unimas.my

Received 2 May 2016; Revised 17 September 2016; Accepted 22 September 2016

Academic Editor: Jakov Dulčić

Copyright (c) 2016 S. A. K. A. Rahim and R. Nurhasan. This is an open access article distributed under the Creative Commons Attribution License, which permits unrestricted use, distribution, and reproduction in any medium, provided the original work is properly cited.

\begin{abstract}
Sea urchins are marine benthos that live in different habitats available at shallow and deep waters. In Malaysia, Sabah is the only state that exploits sea urchins without knowing the status of natural stocks. This study identified the sea urchin species diversity at shallow subtidal zones in east coast of Borneo which is part of the Coral Triangle. Belt transects were deployed to quantify the species composition and qualitative observations on the habitat types were also noted. Simultaneously, documentation of species available in several wet markets was gathered through impromptu conversation with the sellers. In this study, a total of 10 species of sea urchin were recorded from 18 sampling sites, namely, Phyllacanthus imperialis, Diadema setosum, D. savignyi, Echinothrix calamaris, Mespilia globulus, Salmacis sphaeroides, Echinometra mathaei, Pseudoboletia maculata, Toxopneustes pileolus, and Tripneustes gratilla. The most dominant one that showed a wide distribution was D. setosum. Three species are new records for Malaysia. Among the study sites, Semporna district showed the highest species number. Our findings illustrate that shallow waters on the eastern part of Borneo support high diversity of sea urchin resources. Future study should explore the sea urchin diversity at deeper waters and also on the west coast of Sabah.
\end{abstract}

\section{Introduction}

Sea urchins (local name: Landak Laut, Tayum, Tehe-tehe) are one type of benthos (phylum Echinodermata, class Echinoidea) which has spherical shape and is covered with long movable spines that live in different marine habitats, from intertidal [1] to deep-sea $[2,3]$ environments. They belong to the same phylum as sea cucumbers, sand dollars, sea lilies, sea stars, sea biscuits, and brittle stars [4]. Habitats of sea urchins include the coral reef areas and also rocky shores covered with seaweed $[5,6]$ and their colour varies among species such as brown, black, purple, green, white, or red. They also act as important grazers in the marine environment due to their habit of eating seaweeds and scraping the benthic microalgae; thus, they play a major role in controlling vegetation growth in the sea [7]. Diet of sea urchins also includes encrusting animals such as barnacles, gastropods, and worms [8].

About 1,000 species of sea urchins have been reported world wide [9] but documentation of its biodiversity in Malaysia is not well established. In Malaysia, sea urchins are being recorded in brief during coral reef monitoring as indicator species for invertebrates category [10-12], while detail information on the biodiversity and ecology is very limited $[13,14]$.

In some Asian and Mediterranean countries, sea urchins are important marine resource due to the highly prized roe [15]. The demand for sea urchin roe is very high in Japan which leads to a well established fishery and resource management $[16,17]$. In Malaysia, Sabah is the only state that has the custom of eating sea urchins' roe and it is being treated as valuable fishery resources especially by Bajau people. Based on preliminary survey before conducting this research, there is no official report on sea urchin landings in Sabah although sea urchin harvesting by coastal communities and marketing activities can be seen all the year round especially in public wet markets. Currently, list of fisheries important species of sea urchin in Sabah is also not available.

Thus, it is timely to make proper documentation about sea urchins' resources for future research needs because collection of sea urchins in such a large amount could also pose a threat to the natural stocks. Therefore, this research was designed to identify species of sea urchins in shallow waters of 

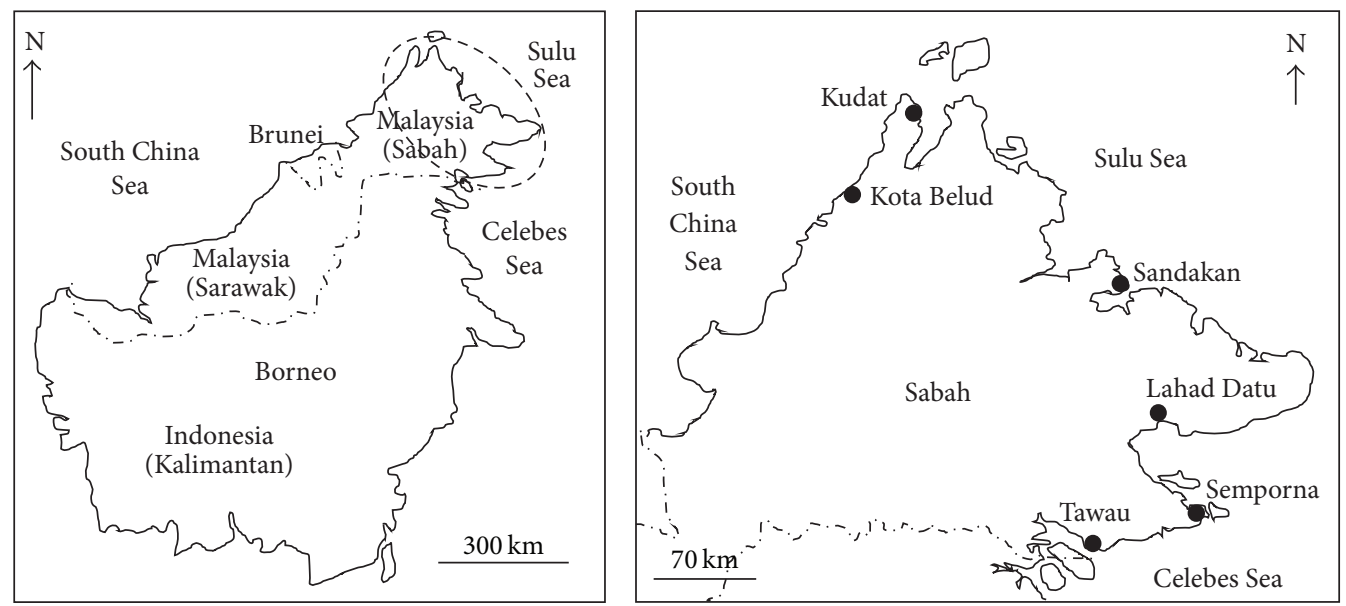

(a)
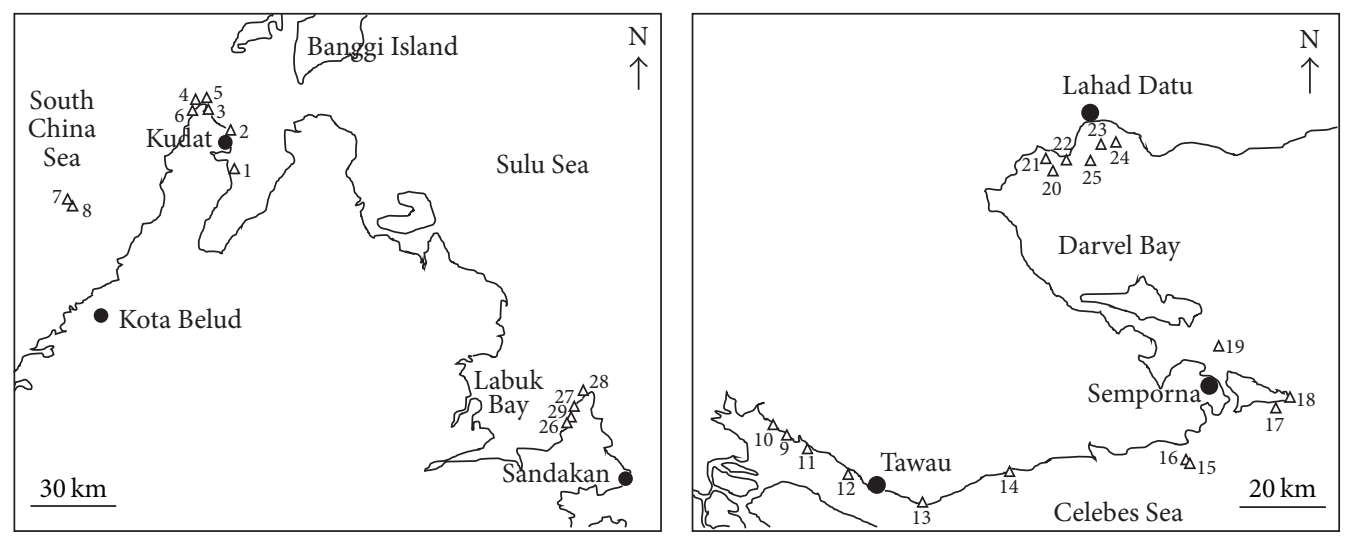

(b)

FIgURE 1: (a) East coast of Borneo Island. (b) The study sites within six districts in Sabah, Malaysia, as follows: 1-Limau-Limauan Beach, 2-BakBak Beach, 3-Suangpai Village Beach, 4-West Simpang Mengayau, 5-East Simpang Mengayau, 6-Kelambu Beach, 7-West Mantanani Island, 8-East Mantanani Island, 9-Udin River, 10-Bingkulan River, 11-Tiram River, 12-Pasir Puteh, 13-Batu Payong, 14-Indrasabah Village, 15-West Manampilik Island, 16-East Manampilik Island, 17-Omadal Island, 18-Bum-Bum Island, 19-Larapan Island, 20-Burung Island, 21-Babi Island, 22-Tiga Island, 23-Tengah Island, 24-West Sakar Island, 25-East Sakar Island, 26-Papan Jambatan, 27-Tikus Island Reef, 28-Tikus Island, and 29-Menangin Island.

Sabah. Data gathered will be useful in providing information on the natural populations of fisheries important species of sea urchins in Sabah, which can be used for conservation and sustainable resource management.

\section{Materials and Methods}

2.1. Study Sites. This research was conducted in Sabah shallow waters which involved 29 study sites in six districts (Figure 1) from December 2010 to November 2011 (Table 1) covering various types of habitat, namely, coral reef, seaweed, and sea grass areas which are known to be the habitat of sea urchins. The water depth of all sites did not exceed $4 \mathrm{~m}$.

2.2. Species Composition and Species Occurrence of Sea Urchins. Determination of sea urchin species composition (\%) was carried out at selected study sites by snorkelers. Three to five belt transects $(5 \mathrm{~m} \times 25 \mathrm{~m})$ were laid perpendicular to the coastline at 11 sampling sites (Stations 1, 3, 4, 5, and 6 in
TABLE 1: Sampling period according to district.

\begin{tabular}{ll}
\hline Sampling period & District (station number) \\
\hline 4 Dec. 2010 & Tawau (9-14) \\
6-7 Dec. 2010 & Semporna (15-18) \\
2 Feb. 2011 & Semporna (19) \\
9 Dec. 2010 & Lahad Datu (20-25) \\
11 Dec. 2010 & Sandakan (26-29) \\
12-13 Dec. 2010 & Kudat (2 and 6) \\
20 \& 25 Nov. 2011 & Kudat (1) \& Kudat (3, 4, and 5) \\
3-4 Dec. 2011 & Kota Belud (7 and 8) \\
\hline
\end{tabular}

Kudat district; Stations 15, 16, and 18 in Semporna district; Stations 20, 22, and 25 in Lahad Datu district) and all sea urchins found within the transect area were counted. However, for study sites that experienced bad sea condition or exhibited patchiness in sea urchin population, the number of 
TABLE 2: The classification of sea urchin collected in Sabah.

\begin{tabular}{lccc}
\hline Order & Family & Genera & Species \\
\hline Cidaroida & Cidaridae & Phyllacanthus & P. imperialis \\
& & Diadema & D. setosum \\
Diadematoida & Diadematidae & & D. savignyi \\
& & Echinothrix & E. calamaris \\
Temnopleuroida & Temnopleuridae & Mespilia & M. globulus \\
& & Salmacis & S. sphaeroides \\
& Echinometridae & Echinometra & E. mathaei \\
& & Pseudoboletia & P. maculata \\
Echinoidea & Toxopneustidae & Toxopneustes & T. pileolus \\
& & Tripneustes & T. gratilla \\
\hline
\end{tabular}

sea urchins encountered was counted randomly and included in reporting the species occurrence. Several specimens were collected for further species identification work in the laboratory using identification keys. The presence and absence of sea urchin for each district and sampling site were presented in table form. The total number of individuals for each sea urchin species was converted into percentage to show the species composition and presented in pie chart and table. Simultaneously, habitat description and seaweed existing at each site were also recorded. Through visits to several wet markets in each district, documentation of edible species was gathered through impromptu conversation with the sellers and local people.

2.3. Physicochemical Parameters. Physicochemical parameters, namely, $\mathrm{pH}$, dissolved oxygen, temperature, turbidity, and salinity, were recorded in situ at subsurface layer using Eu-Tech Multiprobe CyberScan 600 PCD650, Eu-Tech Portable Turbidimeter TN100, and Refractometer Milwaukee MR100ATC.

\section{Results and Discussion}

Throughout this study, a total of 10 sea urchin species from four orders, five families, and nine genera had been identified (Table 2), namely, Phyllacanthus imperialis, Diadema setosum, D. savignyi, Echinothrix calamaris, Mespilia globulus, Salmacis sphaeroides, Echinometra mathaei, Pseudoboletia maculata, Toxopneustes pileolus, and Tripneustes gratilla. Based on the spine morphology, these sea urchins can be divided into three categories: (i) pencil sea urchin that has very thick and blunt spines (P. imperialis), (ii) long-spined sea urchin which has needle like spines and very brittle (D. setosum, D. savignyi, and E. calamaris), and (iii) short-spine sea urchin (M. globulus, S. sphaeroides, E. mathaei, P. maculata, T. pileolus, and T. gratilla).

In total, 13 sea urchins species were already identified in Malaysia (Table 3). However, the presence of sea urchins as reported by Reef Check $[10,11]$ is based on their general common names (Diadema urchins, Collector urchin, and Pencil urchin) without stating the scientific name. Since the Pencil urchin consists of several genera, $P$. imperialis is considered as one of the new records for Malaysian waters. Compared with
TABLE 3: Comparison of species lists between the present study and other records in Malaysia. (+): present and (-): absent.

\begin{tabular}{lcc}
\hline Species & Present study & $\begin{array}{c}\text { Other records in } \\
\text { Malaysia } \\
{[10,11,13,14,18]}\end{array}$ \\
\hline Phyllacanthus imperialis & + & - \\
Diadema setosum & + & + \\
D. savignyi & + & + \\
Echinothrix calamaris & + & + \\
E. diadema & - & + \\
Mespilia globulus & + & - \\
Salmacis sphaeroides & + & + \\
Echinometra mathaei & + & + \\
Pseudoboletia maculata & + & - \\
Toxopneustes pileolus & + & + \\
Tripneustes gratilla & + & + \\
Parasalenia gratiosa & - & + \\
Astropyga radiata & - & + \\
\hline
\end{tabular}



FIGURE 2: Species composition of sea urchins found in Sabah waters.

previous sea urchin species that had been recorded in coral reefs of Malaysia [10,11,13,14,18], three species are new records ( $P$. imperialis, $M$. globulus, and $P$. maculata) and three species were not found in this study (Astropyga radiata, E. diadema, and Parasalenia gratiosa).

The total number of sea urchins found in this study was 3,441 individuals. Based on the overall species composition (Figure 2), D. setosum showed the highest percentage (89.8\%) followed by D. savignyi (7\%), E. calamaris (1.69\%), T. gratilla (0.61\%), T. pileolus $(0.38 \%), M$. globulus, and P. imperialis (0.14\%, resp.), P. maculata and S. sphaeroides $(0.09 \%$, resp.), and lastly E. mathaei (0.06\%).

In terms of species occurrence based on 29 sampling sites, 18 sites recorded the presence of sea urchin which ranged from a minimum of one species to a maximum of seven species found (Table 4). Semporna, Kudat, Lahad Datu, and Kota Belud districts showed presence of sea urchin but no sea 


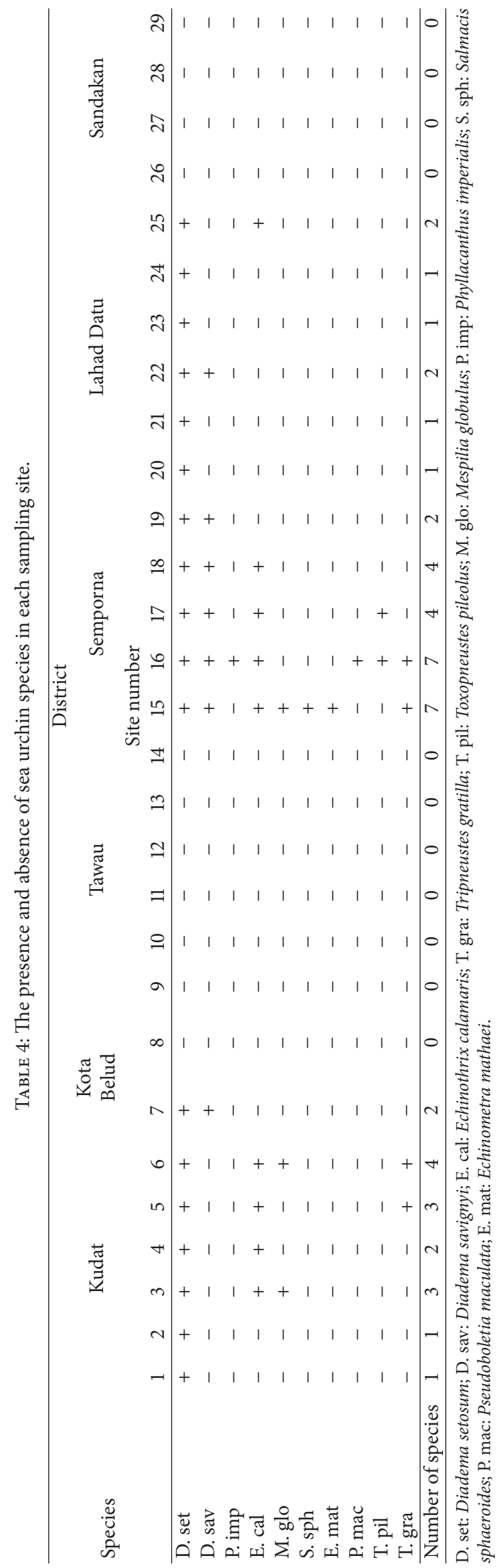


TABLE 5: The species abundance (\%) of sea urchins according to districts, (-): absent.

\begin{tabular}{lccc}
\hline \multirow{2}{*}{ Species } & \multicolumn{3}{c}{ Abundance (\%) } \\
& Kudat & Lahad Datu & Semporna \\
\hline Phyllacanthus imperialis & - & - & 0.74 \\
Diadema setosum & 98.38 & 98.62 & 54.21 \\
D. savignyi & - & 1.25 & 32.64 \\
Echinothrix calamaris & 0.94 & 0.13 & 6.65 \\
Mespilia globulus & 0.34 & - & 0.15 \\
Salmacis sphaeroides & - & - & 0.44 \\
Echinometra mathaei & - & - & 0.30 \\
Pseudoboletia maculata & - & - & 0.44 \\
Toxopneustes pileolus & - & - & 1.92 \\
Tripneustes gratilla & 0.34 & - & 2.51 \\
\hline
\end{tabular}

urchin was found at all sampling sites in Tawau and Sandakan. Semporna district showed the highest species composition with a total of ten species found in which both West Manampilik Island and East Manampilik Island recorded seven species at each site. In Kudat district, four species were found and highest location was at Kelambu Beach. In Lahad Datu district, three species were found in which both Tiga Island and East Sakar Island recorded two species at each site. In Kota Belud district, two species were found at North Mantanani Island. Among the ten species, the well distributed species was $D$. setosum, while $P$. imperialis, $S$. sphaeroides, $P$. maculata, and E. mathaei occurred at one sampling site in Semporna district.

The species abundance (\%) of sea urchins according to districts showed that family Diadematidae which is composed of three species (D. setosum, D. savignyi, and E. calamaris) dominated all districts (Table 5). The dominancy of $D$. setosum was clearly observed in Kudat and Lahad Datu, while this species contributed to slightly more than half of the sea urchin assemblage in Semporna. Among districts, the highest percentage of D. savignyi, E. calamaris, and T. gratilla was recorded in Semporna.

The reasons for the difference of species composition, species abundance, and species occurrence at each study site could be related to the physicochemical parameters of water (Table 6), food availability, and protection from predation. Turbidity at Semporna, Kudat, and Lahad Datu is better compared to Sandakan and Tawau. Turbid water and lower values in dissolved oxygen (DO) were observed in Tawau and Sandakan due to river discharges, resulting in poor light penetration which will not support the natural formation of coral, seagrass bed, and seaweed growth. A low DO value also indicates that the habitat cannot provide an optimum condition for other marine organisms which are important in maintaining a healthy food web of sea urchin community.

Seagrass and seaweed are the main diet for most sea urchins such as T. gratilla, E. calamaris, and S. sphaeroides while some species such as E. mathaei, D. setosum, and D. savignyi feed on encrusting organisms and coral or coral rubble [19]. The seagrass, seaweed, and coral reef areas in Semporna, Lahad Datu, and Kudat serve as sea urchin feeding ground which is good for growth and gonad production. According to Tsuda et al. [20], growth and gonad production of sea urchins are greatly affected by algal species as foods and standing crops.

Results showed that the species occurrence of sea urchins seems to be influenced by availability of suitable habitats such as coral reef, sea grass, and seaweed at the four districts. General description of each sampling site involved was recorded in order to know the habitat of sea urchin (Tables 7 and 8). Semporna provides coral reef area, rocky area, seaweed, and seagrass beds for protection and food of sea urchin as well as Lahad Datu, Kota Belud, and Kudat. Tawau and Sandakan lack certain important habitat which is coral reef and seagrass that is very important for sea urchin protection and shelter. Sampling sites at Tawau were located at seaweed farms and rocky shores area. Sea urchins at Semporna were found at various types of habitat, namely, coral reefs area (mostly soft coral), seagrass, seaweed, and rocky area. In Lahad Datu, sea urchins were found at coral rubbles, coral reefs, and seaweed areas. Sandakan sampling sites were located at rocky beaches and seaweed areas. In Kudat, sea urchins were found at coral reef (soft and hard coral), coral rubbles, rocky area, seaweed, and seagrass areas. In Kota Belud, sea urchins were found at seagrass beds, seaweed area, coral reef, reef ball area, and some debris appearance.

Pristine or less disturbed natural habitats offer ample food sources to sea urchins and also play important role in specific behaviour of sea urchins towards their survival $[1,21]$. For instance, D. setosum exhibited aggregation behaviour that can protect them against predation, while other species used to camouflage with their surroundings by hiding in the rock crevices (E. mathaei), holding coral rubbles on the aboral side (T. pileolus), or rolling seagrass blades around its test ( $T$. gratilla). Habitats with greater structural complexity provide shelter and can also reduce predation rates which are preferred by sea urchins [22] since predation also contributes to altering echinoid distribution as well as abundance [23].

Furthermore, habitat specific cues also play an important role in sea urchin larval settlement and population recruitment $[24,25]$. Seagrass, seaweed, and microbial films have been associated with sea urchin larval settlement [26-31] that requires suitable substratum to settle and ends with metamorphosis [32]. The metamorphosis of T. gratilla larvae was higher in response to macroalgae and seawater conditioned with macroalgae, but marine biofilm gave a lower response $[33,34]$. In contrast, the larvae of Paracentrotus lividus showed higher settlement on rock wall covered with biofilm compared to seagrass meadow [35].

Sea urchin resources in Sabah are being exploited for local consumption without any regulation. Simple traditional method was used for sea urchin collection by Bajau Semporna and Ubian ethnics. Semporna has been identified as the main district in Sabah that harvests and markets sea urchin the most. A total of six species of edible sea urchin have been identified: D. setosum, D. savignyi, T. gratilla, E. calamaris, P. maculata, and T. pileolus. The most common edible sea urchins are Diadema spp. (Tayum) and T. gratilla (Tehe-tehe) which are commonly sold in the wet market while other species were collected for own consumption. Diadema spp. 
TABLE 6: Range of mean values of in situ physicochemical parameters ( $\mathrm{pH}$, temperature, turbidity, salinity, and dissolved oxygen) among 29 sampling sites in six districts.

\begin{tabular}{|c|c|c|c|c|c|}
\hline \multirow[b]{2}{*}{ District } & \multicolumn{5}{|c|}{ Range of mean value } \\
\hline & $\mathrm{pH}$ & $\begin{array}{c}\text { Temperature } \\
\left({ }^{\circ} \mathrm{C}\right)\end{array}$ & $\begin{array}{l}\text { Turbidity } \\
\text { (NTU) }\end{array}$ & $\begin{array}{l}\text { Salinity } \\
\text { (PSU) }\end{array}$ & $\begin{array}{c}\mathrm{DO} \\
(\mathrm{mg} / \mathrm{L})\end{array}$ \\
\hline Kudat & $7.34-8.18$ & $31.00-33.00$ & $0.79-2.37$ & $30.00-31.00$ & $9.75-12.81$ \\
\hline Kota Belud & $7.18-7.31$ & $30.10-30.60$ & $4.59-8.72$ & $31.00-34.00$ & $7.04-7.47$ \\
\hline Tawau & $6.10-7.89$ & $29.50-31.00$ & $4.40-53.50$ & $30.00-33.00$ & $4.95-7.97$ \\
\hline Semporna & $7.96-8.19$ & $27.50-29.60$ & $0.34-1.06$ & $33.00-35.00$ & $7.02-7.73$ \\
\hline Lahad Datu & $7.83-8.10$ & $29.60-31.70$ & $0.00-0.63$ & $32.00-35.00$ & $7.07-11.75$ \\
\hline Sandakan & $7.60-7.82$ & $28.90-29.40$ & $3.85-17.34$ & $34.00-35.00$ & $6.23-6.89$ \\
\hline
\end{tabular}

TABLE 7: The description of habitat at each sampling site by districts.

\begin{tabular}{|c|c|c|}
\hline District & Sampling site & Description \\
\hline \multirow{6}{*}{ Kudat } & Limau-Limauan Beach & Rocky areas, coral rubbles \\
\hline & Bak-Bak Beach & Rocky areas, seagrass bed, seaweed \\
\hline & Suang Pai Beach & Coral reef, seaweed, seagrass \\
\hline & West Simpang Mengayau & Rocky areas (big rocks), seaweed, coral reef \\
\hline & East Simpang Mengayau & Seagrass, seaweed, coral reef, rocky areas (small rocks) \\
\hline & Kelambu Beach & Rocky areas, coral reef, coral rubbles, debris \\
\hline \multirow{2}{*}{ Kota Belud } & North Mantanani & Reef ball, seagrass, seaweed, coral reef \\
\hline & South Mantanani & Seagrass, seaweed, debris \\
\hline \multirow{6}{*}{ Tawau } & Udin Estuary & Seaweed (Kappaphycus and Eucheuma) farm \\
\hline & Bingkulan Estuary & - \\
\hline & Tiram Estuary & - \\
\hline & Pasir Puteh Estuary & Rocky areas \\
\hline & Batu Payong & Rocky areas \\
\hline & Inderasabah Village & Fishing village \\
\hline \multirow{5}{*}{ Semporna } & West Manampilik Island & Coral reef, rocky areas, seagrass, less seaweed \\
\hline & East Manampilik Island & Coral reef, rocky areas, seagrass, seaweed, coral rubble \\
\hline & Omadal Island & Coral reef, seaweed, rocky areas \\
\hline & Bum-Bum Island & Coral reef, seaweed, seagrass \\
\hline & Larapan Island & Coral reef, seaweed \\
\hline \multirow{6}{*}{ Lahad Datu } & Burung Island & Less coral, rocky areas, sandy area, coral rubbles, seaweed \\
\hline & Babi Island & Rocky areas, coral rubble \\
\hline & Tiga Island & Coral reef \\
\hline & Tengah Island & Coral reef \\
\hline & West Sakar Island & Coral reef, rocky areas, sandy area \\
\hline & East Sakar Island & Coral reef, rocky areas, sandy area \\
\hline \multirow{4}{*}{ Sandakan } & Papan Jambatan & Rocky areas \\
\hline & Menangin Island & Rocky areas, sandy area \\
\hline & Tikus Island Rocky Areas & Rocky areas \\
\hline & Tikus Island & Rocky areas, sandy area \\
\hline
\end{tabular}

can be easily found because they tend to aggregate in high abundance at shallow waters of seagrass, seaweed, coral reef, and rocky area. Reduction of sea urchin natural population size due to fishing pressure had been reported in Japan [36] and Barbados [37]. In the later case, the sea urchin fishery collapsed and resulted in major loss of employment. Nowadays, large amount of sea urchins is being collected especially in the east coast of Sabah and this could pose a threat to the natural stocks. Other causes that also led to decline in sea urchins abundance are habitat disturbance due to high sedimentation from rivers and habitat lost by dynamite and cyanide fishing in coral reef area.

Overall, specific factors associated with sea urchin species diversity in the east coast of Borneo are not clear yet and may involve very complex abiotic-biotic interactions which need to be addressed in future. Nevertheless, findings of this 
TABLE 8: List of main seaweeds genera available at each district.

\begin{tabular}{ll}
\hline District & Seaweed genera \\
\hline Kudat & $\begin{array}{l}\text { Caulerpa, Halimeda, Spatoglossum, Turbinaria, } \\
\text { Udotea }\end{array}$ \\
Kota Belud & Not collected \\
Tawau & Not collected \\
Semporna & Caulerpa, Halimeda. Padina, Sargassum \\
Lahad Datu & Caulerpa, Laurencia, Padina, Sargassum, \\
Sandakan & Turbinaria, Tydemania \\
\hline
\end{tabular}

study managed to give partial information on sea urchin resources of Sabah which is part of the Coral Triangle since the species checklist documented did not cover the deeper waters $(>4 \mathrm{~m})$ and the west coast of Sabah and thus may underestimate the real sea urchin diversity. However, these findings are useful in providing ecological information on the natural populations of fisheries important species of sea urchins in Sabah, which can be used for conservation and sustainable resource management.

\section{Conclusions}

A total of 10 species of sea urchin were recorded from 18 sampling sites, namely, $P$. imperialis, D. setosum, D. savignyi, E. calamaris, M. globulus, S. sphaeroides, E. mathaei, P. maculata, T. pileolus, and T. gratilla. Three species are new records for Malaysia. Among the study sites, Semporna district showed the highest species composition and also supports a smallscale sea urchin fishery in providing subsistence income to the local coastal communities. Out of 10 documented species, six sea urchin species are edible, namely, D. setosum, D. savignyi, T. gratilla, E. calamaris, P. maculata, and $T$. pileolus, in which Diadema spp. and T. gratilla are the main marketed species. In order to become sea urchin roe exporter to the international market in future, a suitable management system should be applied to sea urchin fishery in Sabah since sustainable fishing is very important to prevent overfishing.

\section{Competing Interests}

The authors declare that there is no conflict of interests regarding the publication of this article.

\section{Acknowledgments}

This project was supported by MOHE Fundamental Research Grant Scheme [07(02)/759/2010(45)]. Thanks are due to all support staffs and local people involved in this study for unlimited assistance during the field trips and data collection.

\section{References}

[1] H. Schultz, Sea Urchins, A Guide To Worldwide Shallow Water Species, Heinke + Peter Schultz Partner Scientific Publications, Hemdingen, Germany, 3rd edition, 2010.
[2] B. G. Hatcher and R. E. Scheibling, "The ecology of Strongylocentrotus droebachiensis," in Edible Sea Urchins: Biology and Ecology, J. M. Lawrence, Ed., pp. 271-306, Elsevier, Amsterdam, The Netherlands, 2001.

[3] M. J. Tegner, "The ecology of Strongylocentrotus franciscanus and Strongylocentrotus purpuratus," in Edible Sea Urchins: Biology and Ecology, J. M. Lawrence, Ed., pp. 301-331, Elsevier, Amsterdam, The Netherlands, 2001.

[4] J. A. Pechenik, Biology of the Invertebrates, McGraw-Hill, New York, NY, USA, 6th edition, 2010.

[5] J. K. Keesing, "The ecology of Heliocidaris erythrogramma," in Edible Sea Urchins: Biology and Ecology, J. M. Lawrence, Ed., pp. 261-270, Elsevier, Amsterdam, The Netherlands, 2001.

[6] F. Tuya, J. Cisneros-Aguirre, L. Ortega-Borges, and R. J. Haroun, "Bathymetric segregation of sea urchins on reefs of the Canarian Archipelago: role of flow-induced forces," Estuarine, Coastal and Shelf Science, vol. 73, no. 3-4, pp. 481-488, 2007.

[7] S. Pinna, G. Ceccherelli, and N. Secchi, "Investigating on the occurrence of Paracentrotus lividus in rocky and Posidonia oceanica habitat," in Proceedings of the 16th Meeting of the Italian Society of Ecology, p. 4, 2006.

[8] M. S. Kelly and E. J. Cook, "The ecology of Psammechinus miliaris," in Edible Sea Urchins: Biology and Ecology, J. M. Lawrence, Ed., pp. 217-224, Elsevier, Amsterdam, The Netherlands, 2001.

[9] Y. Yokota, "Introduction to the sea urchin biology," in The Sea Urchin: From Basic Biology to Aquaculture, Y. Yokota, V. Matranga, and Z. Smolenicka, Eds., pp. 1-10, Balkema, Lisse, The Netherlands, 2002.

[10] N. Ho and K. Kassem, Reef Status of Semporna Priority Conservation Area, WWF-Malaysia, Kota Kinabalu, Malaysia, 2009.

[11] Reef Check Malaysia, Status of Coral Reef in Malaysia 2010. Annual Survey Report, WWF, Kuala Lumpur, Malaysia, 2010.

[12] Z. Waheed, F. A. F. Adnan, L. C. Hwa, and S. R. M. Hashim, "Status of coral reef sand sedimentation at Kota Kinabalu: a preliminary study at Gaya Bay and Sepangar Bay," Borneo Science, vol. 21, pp. 29-44, 2007.

[13] M. R. Siti Shazlina, Y. Yusuf, M. H. Norainy, and A. Amirrudin, "Species diversity and distribution of sea urchin at Bidong Island," in Proceedings of the International Conference on the Marine Ecosystems, pp. 502-506, Langkawi, Malaysia, May 2009.

[14] A. A. A. Kee, Biology and ecology aspects of sea urchin (Diadema setosum) in Tioman Islands [M.S. thesis], National University of Malaysia, Bangi, Malaysia, 2003.

[15] N. A. Sloan, "Echinoderm fisheries of the world: a review," in Proceedings of the 5th International Echinoderm Conference, pp. 109-124, Balkema, Galway, Ireland, September 1985.

[16] N. L. Andrew, Y. Agatsuma, E. Ballesteros et al., "Status and management of world sea urchin fisheries," in Oceanography and Marine Biology: An Annual Review, vol. 40, pp. 343-425, 2002.

[17] Y. Agatsuma, Y. Sakai, and N. L. Andrew, "Enhancement of Japan's sea urchin fisheries," in Sea Urchins: Fisheries and Ecology, J. M. Lawrence and O. Guzmán, Eds., pp. 18-36, DEStech, Lancaster, UK, 2004.

[18] M. A. Rahman, S. M. N. Amin, F. Md. Yusoff, A. Arshad, P. Kuppan, and M. Nor Shamsudin, "Length weight relationships and fecundity estimates of long-spined Sea Urchin, Diadema setosum, from the Pulau Pangkor, Peninsular Malaysia," Aquatic Ecosystem Health and Management, vol. 15, no. 3, pp. 311-315, 2012. 
[19] J. M. Lawrence, "On the relationships between marine plants and sea urchins," Oceanography and Marine Biology, vol. 13, pp. 213-286, 1975.

[20] F. Tsuda, H. Hoshikawa, Y. Agatsuma, and K. Taniguchi, "Gonad production of the sea urchin Strongylocentrotus nodus in relation to algal vegetation in shallow waters along the Sea of Japan, Southwestern Hokkaido Japan," Scientific Report of Hokkaido Fisheries Experimental Station, vol. 71, pp. 63-68, 2006.

[21] J. M. Lawrence and Y. Agatsuma, "The ecology of Tripneustes," in Edible Sea Urchins: Biology and Ecology, J. M. Lawrence, Ed., pp. 395-413, Elsevier, Amsterdam, The Netherlands, 2001.

[22] B. Hereu, M. Zabala, C. Linares, and E. Sala, "The effects of predator abundance and habitat structural complexity on survival of juvenile sea urchins," Marine Biology, vol. 146, no. 2, pp. 293-299, 2005.

[23] J. M. Lawrence and P. W. Sammarco, "Effects of feeding: echinoidea," in Echinoderm Nutrition, M. Jangoux and J. M. Lawrence, Eds., pp. 499-519, A. A. Balkema, Rotterdam, The Netherlands, 1982.

[24] J. R. Pawlik, "Chemical ecology of the settlement of benthic marine invertebrates," Oceanography and Marine Biology: An Annual Review, vol. 30, pp. 273-335, 1992.

[25] M. G. Hadfield and V. J. Paul, "Natural chemical cues for the settlement and metamorphosis of marine invertebrate larvae," in Marine Chemical Ecology, J. G. McClintock and B. J. Baker, Eds., pp. 431-461, CRC Press, Boca Raton, Fla, USA, 2001.

[26] I. Kawahara, "Seed production of sea urchins (Pseudocentrotus depressus and Hemicentrotus pulcherrimus)," in Manual of Saga Prefectural Fish Farming Center for Seed Production, pp. 4568, Saga Prefectural Fish Farming Center, Saga, Japan, 1996 (Japanese).

[27] R. J. Rowley, "Settlement and recruitment of sea urchins (Strongylocentrotus spp.) in a sea-urchin barren ground and a kelp bed: are populations regulated by settlement or postsettlement processes?” Marine Biology, vol. 100, no. 4, pp. 485494, 1989.

[28] C. M. Pearce and R. E. Scheibling, "Effect of macroalgae, microbial films, and conspecifics on the induction of metamorphosis of the green sea urchin Strongylocentrotus droebachiensis (Müller)," Journal of Experimental Marine Biology and Ecology, vol. 147, no. 2, pp. 147-162, 1991.

[29] S. A. K. A. Rahim, J.-Y. Li, and H. Kitamura, "Larval metamorphosis of the sea urchins, Pseudocentrotus depressus and Anthocidaris crassispina in response to microbial films," Marine Biology, vol. 144, no. 1, pp. 71-78, 2004.

[30] S. A. Rahim, J. Li, C. G. Satuito, and H. Kitamura, "The role of diatom-based film as an inducer of metamorphosis in larvae of two species of sea urchin, Pseudocentrotus depressus and Anthocidaris crassispina," Sessile Organisms, vol. 21, no. 1, pp. 712, 2004.

[31] R. L. Swanson, J. E. Williamson, R. De Nys, N. Kumar, M. P. Bucknall, and P. D. Steinberg, "Induction of settlement of larvae of the sea urchin Holopneustes purpurascens by histamine from a host alga," Biological Bulletin, vol. 206, no. 3, pp. 161-172, 2004.

[32] S. R. Rodriguez, F. P. Ojeda, and N. C. Inestrosa, "Settlement of benthic marine invertebrates," Marine Ecology Progress Series, vol. 97, no. 2, pp. 193-207, 1993.

[33] S. A. Dworjanyn and I. Pirozzi, "Induction of settlement in the sea urchin Tripneustes gratilla by macroalgae, biofilms and conspecifics: a role for bacteria?" Aquaculture, vol. 274, no. 2-4, pp. 268-274, 2008.
[34] B. Mos, K. L. Cowden, S. J. Nielsen, and S. A. Dworjanyn, “Do cues matter? Highly inductive settlement cues don't ensure high post-settlement survival in sea urchin aquaculture," PLoS ONE, vol. 6, no. 12, article e28054, 2011.

[35] F. Tomas, J. Romero, and X. Turon, "Settlement and recruitment of the sea urchin Paracentrotus lividus in two contrasting habitats in the Mediterranean," Marine Ecology Progress Series, vol. 282, pp. 173-184, 2004.

[36] J. Taki, "Population dynamics of Strongylocentrotus intermidius in Akkeshi Bay," in Scientific Report of Hokkaido Fisheries Experimental Station, vol. 28, pp. 33-43, 1986 (Japanese with English abstract).

[37] R. E. Scheibling and P. V. Mladenov, “The decline of the sea urchin, Tripneustes ventricosus fishery of Barbados: a survey of fishermen and consumers," Marine Fisheries Review, vol. 49, no. 3, pp. 62-69, 1987. 



Submit your manuscripts at

http://www.hindawi.com
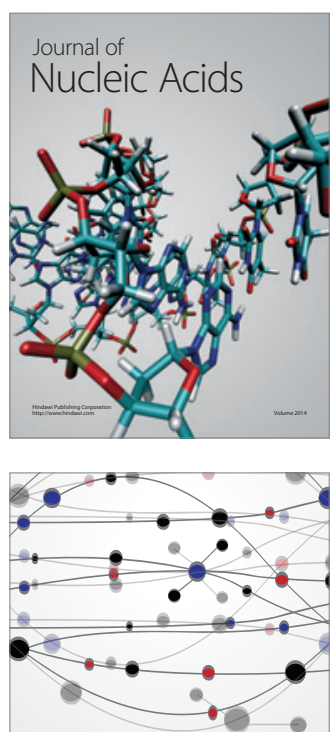

The Scientific World Journal
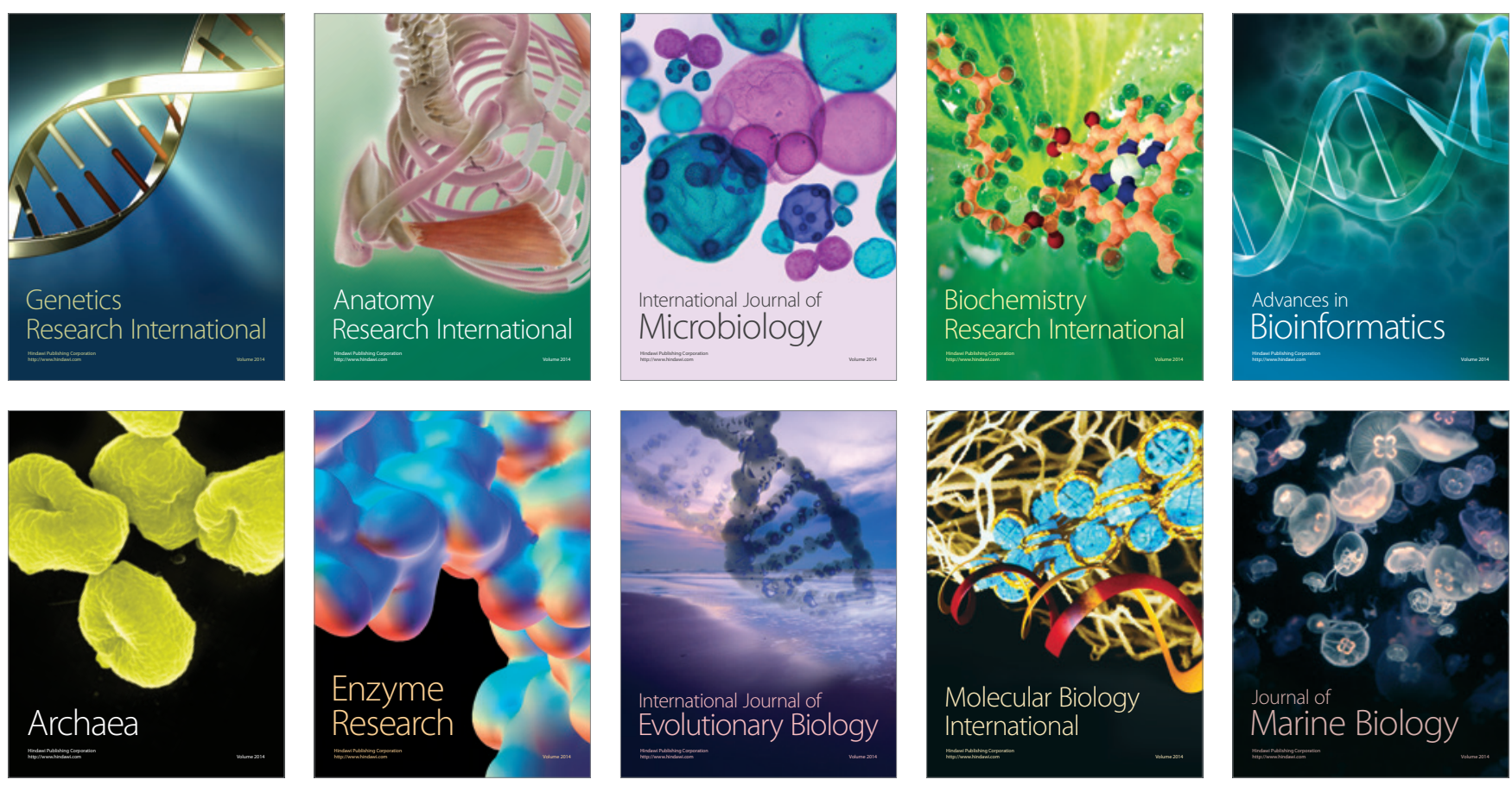